\title{
Strategic Analysis of School-enterprise Cooperation, Production and Education Integration and Reform of Talent Cultivation Model in Higher Vocational Colleges
}

\author{
Ping Liu \\ Liaoningjianzhu Vocational College, Liaoning, Liaoyang, 111000
}

Keywords: school-enterprise cooperation; integration of production and education; higher vocational colleges; talent training; model innovation

\begin{abstract}
Higher vocational colleges are an important place for the cultivation of social applied talents in China. Faced with the new requirements of talents in the "new era" society, higher vocational colleges should enhance the attractiveness of running schools and transform through "integration of production and education, cooperation between schools and enterprises". The mode of running a school in the traditional teaching process adapts to the situation of the cultivation of applied talents in higher vocational schools in the new economic era. Specifically, in the practice of school-enterprise cooperation and the integration of production and education, higher vocational colleges should adhere to the principle of "win-win" and overcome the problems of weak cooperation, poor education and weak practical ability of school-enterprise cooperation, deepen the reform of teaching as a breakthrough, strengthen the construction of professional practice curriculum system, pay attention to the integration of production and education, the integration and coordination of advantages and disadvantages of industry and industry, fully explore and cultivate the new business mode of school-enterprise cooperation and education, realize resource coordination and promote high vocational students' ability to innovate.
\end{abstract}

\section{Introduction}

Under the background of social and educational transformation, the current era has higher and higher requirements for the comprehensive quality of talents in higher vocational colleges. The traditional single school-running model has been unable to adapt to the innovative requirements of talents in the new era. In this context, "school-enterprise cooperation, integration of production and education", with its innovative features, provides an important channel for the reform of talent training mode in higher vocational colleges, highlighting the characteristics of the school-running and talent training mode of higher vocational colleges in the new era [1]. "School-enterprise cooperation, integration of production and education" is also called cooperative education. It mainly focuses on enterprises and schools, and aims at improving students' professional ability, practical ability and comprehensive quality. Through the two places, two main bodies and multiple modes of enterprise and school, we will make full use of the opportunity of integration of production and education to cultivate innovative and applied talents for society and enterprises.

\section{Existing Problems in Talent Training in Higher Vocational Colleges}

Higher vocational colleges bear the important function of cultivating applied talents for China's economy and society. However, the current vocational colleges have a weak foundation in cooperation with enterprises in running schools. Since the enterprise is the main body of the social production and management activities, and the school is the public welfare personnel training institution, there is a big difference in the cooperation property between the two talent cultivation subjects. For higher vocational colleges, it is hoped that through school-enterprise cooperation, the quality of school education and the level of innovation in talent cultivation will be improved. For enterprises, the core purpose is to obtain high-quality applied talents through the school's educational institution. This optimizes the enterprise human resource configuration structure. This 
kind of demand difference leads to a weak foundation for cooperation between the two sides. Most of the school-running bodies maintain their development through interpersonal relationships. For a long time, due to unbalanced interests, unstructured structures, unsound mechanisms, and lack of coordination and coordination, the application of talents in higher vocational colleges The cultivation is out of line with the needs of the society; in addition, some enterprises have limited technology, equipment and practice sites, and resources cannot be shared with universities, which brings great pressure on schools and schools. In the long run, it will dampen the enthusiasm of school-enterprise cooperation in running schools. In addition, in the past school-enterprise cooperation in running schools, the school's service investment to enterprises was less, and the company's product development and technology research capabilities were limited, and it was not effectively linked to social needs.

Generally speaking, higher vocational colleges and enterprises cooperate with production activities as the carrier, but enterprises are driven by economic interests. In the school-enterprise cooperation, the actual input and output benefits will be measured. In particular, in the process of running a school, the educational activities of productive activities are not prominent, and the guiding significance for students' social practice is not obvious. The reason for this situation is that the enthusiasm of enterprises in school-enterprise cooperation in education and education is not high. Some enterprises even believe that cooperation in running schools is a platform for students to provide socialized practice, and the responsibility of educating students lies in schools. As a result, the company's awareness of school innovation in school-enterprise cooperation is not strong, and there is a lack of procedures and content optimization design for professional practice projects. Therefore, students' participation and interaction in educational practice are not prominent. In addition, some higher vocational colleges only cooperate for school-enterprise cooperation, lack of screening for enterprises, and blindly cooperate with enterprises to carry out social productive projects, which reduce the quality of personnel training [2]. Most schools can only rely on enterprises, and arrange professional internships for students according to their daily production tasks. Although the linear working mode is relatively stable, it lacks the training and training of students' social practice ability.

"School-enterprise cooperation" is a common talent training mode in higher vocational colleges. However, due to the lack of integration of production and education in the practice of school-enterprise cooperation, the impact of the cooperation model on students is relatively limited, especially as some enterprises are equipped with students. Training instructors, but corporate instructors are usually composed of managers or engineering and technical personnel. These practical instructors generally lack practical teaching and guidance experience, so the impact on students' comprehensive practical skills and knowledge learning is not significant. During the training process, some training teachers have established good mentoring relationships with students, and are responsible for technical guidance and education, and they are responsible for their duties. Some training instructors are subject to personality factors or busy work, and students. The relationship is not harmonious. In addition, some enterprises have insufficient number of practical guidance teachers for students, and the training guidance is not in place, thus reducing the initiative of students' school-enterprise cooperation and participation [3].

\section{3. "School-Enterprise Cooperation" - "Integration of Production and Education" and the Reform Strategy of Talent Training Mode in Higher Vocational Colleges}

"School-enterprise cooperation" - "integration of production and education" has provided strong support for the reform of the talent training model in higher vocational colleges. In view of the current weak cooperation, lack of education and weak students' ability in the cooperation between university and enterprise in higher vocational colleges, higher vocational colleges should highlight higher vocational education through the integration of production and education on the basis of deepening cooperation between schools and enterprises. The characteristics of personnel training in colleges and universities promote the reform of education and teaching. Under the premise of optimization and adjustment of professional structure, we must strengthen the efforts to realize the 
collaborative education of schools and provide students with social practical teaching and education platforms, so that students' diversified innovation skills can be fully demonstrated. To meet the special needs of society for applied talents.

"School-enterprise cooperation, integration of production and education" is an important feature of cultivating applied and innovative talents in higher vocational colleges in the new era. School-enterprise cooperation and the pattern of integration of production and education require higher vocational colleges to make full use of the existing material, human and financial resources of the enterprise, and to deepen the cooperation between schools and enterprises in light of actual needs, and establish and improve the production and education between higher vocational colleges and enterprises. In terms of professional setting, we should focus on social needs, formulate special talent training programs, rationally optimize and adjust the professional structure, and enable schools and enterprises to jointly undertake the responsibility of cultivating "application-oriented" talents and serve regional economic and social development [4]. Higher vocational colleges should also arrange professional teachers to serve in the enterprise and enrich their social practice experience in order to provide classroom teaching and social practical teaching guidance to students. Enterprises must cultivate "double-skilled" teachers, enhance social service awareness and distinctive talent training awareness, enhance comprehensive service capabilities and levels, and take a new and sustainable approach to integration of production and education.

The school-enterprise cooperation, the integration of production and education, the school-running model requires higher vocational colleges to actively carry out teaching reforms, comprehensively promote social practice, "to promote learning through education", combine the rules and characteristics of personnel training, and integrate production and education according to the needs of enterprises. Really put into the production practice of enterprises and professional education in higher vocational colleges, and set up professional special courses, focusing on improving students' creative ability, strengthening students' sense of innovation, realizing professional curriculum construction, enterprise production training base construction and industry With the adjustment of industry structure, the mature and advanced social production technology is the forerunner, and the enterprise specialization position is taken as the guarantee. According to the "post-capability-course" support relationship, the professional courses of higher vocational colleges will be reset and optimized. The combination of theoretical cognition and professional post-internship practice, internalize and strengthen students' practical ability, focus on technical aspects and comprehensive quality, vigorously promote the "artisan spirit" in the cultivation of applied talents, and strengthen students' meticulousness. , "excellence" social responsibility awareness, enabling it to innovatively on the practice used in the production of enterprises laid a good foundation for service to the community.

Higher vocational colleges should be based on the favorable opportunity of "school-enterprise cooperation, integration of production and education", focusing on the convergence of advantageous industries and industries. In the professional structure setting and professional curriculum construction, the professional group, professional courses and professional positions of the school-enterprise counterparts should be set up. At the same time, higher vocational colleges should be actively adapted to the needs of the society, actively promote the reform of production practice, optimize the professional within the school, and pay attention to the regional economy. The new situation of social development transformation, combined with the characteristics of industrial structure and the special requirements of the society for talent training, market-oriented, focusing on the optimization of industrial structure, vigorously deploying the superior resources of enterprises and schools, so that schools can match the market supply and demand. To carry out the "order-based" talent training program, so that the new-type talents trained by the school-enterprise can adapt to the position of the enterprise and connect with the enterprise and society. The achievement of this goal needs to be ensured by a sound professional structure and education mechanism. It requires schools and enterprises to deepen the research on talent training path, adjust talent training programs in a timely and timely manner, and establish an early warning mechanism for integration of production and education. According to regional development changes, regular or 
From time to time, relevant experts are invited to conduct special seminars to predict the impact of professional settings and corporate positions on the economy and society. This will improve the forward-looking nature of higher vocational colleges in professional education and stimulate the vitality of school-running.

"School-enterprise cooperation, integration of production and education" collaborative education mainly refers to the cooperation between schools and enterprises to cultivate innovative talents, on the one hand to achieve the goal of teaching reform in higher vocational colleges, on the other hand, to lay a good foundation for the optimal allocation of talent structure . Collaborative education and integration of production and education as an important way of education reform in higher vocational colleges can solve the outstanding problems existing in the two aspects of homogenization of running schools, inefficient school-running and relatively low-quality school-running resources, and can continue to improve. The process and mechanism of "collaborative education" follows the law of talent cultivation, pays attention to the improvement of the quality of collaborative education, and gives full play to the characteristics of higher vocational colleges and enterprises in their respective careers, so as to meet the breadth of talent cultivation in school, enterprise, education and education. Diversified needs in terms of height and depth, realize the backbone replacement of talents in enterprises and higher vocational colleges, exchange student classrooms and enterprise workshops, and link the corporate goals with the teaching objectives of professional courses in higher vocational colleges, and share high-quality resources [5].

\section{Conclusion}

In view of the problems existing in the current vocational colleges and enterprises in the process of cooperation in running schools, higher vocational colleges should be based on the new situation, with the core of cultivating innovative, distinctive and applied talents, focusing on corporate resources, technology and talents. Advantages, through deepening the "school-enterprise cooperation", the new school-running model based on "integration of production and education", highlighting the characteristics of talent training in higher vocational colleges, deepening education and teaching reform, according to the actual feedback of the society on the talents of higher vocational colleges In time, we will adjust and optimize the professional structure of "school-enterprise cooperation", vigorously promote the work of collaborative education, and give full attention to practical education. According to the objective requirements of current regional economic and social development for applied talents, we will innovate the mode of running higher education institutions and training talents, further deepen the integration of production and education, fill in the shortcomings of talents, and concentrate on solving the training of applied talents in higher vocational colleges. The outstanding problems that are not closely integrated with the needs of economic and social development are to promote the long-term and diversified development of higher vocational colleges.

\section{References}

[1] Hu Shunli. Feasibility study on the training mode of international cruise crews in higher vocational colleges under the mechanism of "integration of production and education, school-enterprise cooperation"[J]. Journal of Kaifeng College of Education, 2014, 34 (07): 191-192.

[2] Zhou Jing, Yue Jinfeng. Report on the cooperation between schools and enterprises for the integration of production and education with modern vocational education with Chinese characteristics since the 18th National Congress [J]. Vocational and Technical Education, 2017, 38 (24): 45-52.

[3] Sun Jie, Zhou Guizhen, Xu Anlin, Wang Zhenhua. Research and Practice on Promoting the Integration of Industry and Education and the Reform of School-enterprise Cooperation Mechanism in Higher Vocational Education-Taking Wuxi Vocational and Technical College as an Example[J]. Vocational and Technical Education in China, 2018, (03): 59-62. 
[4] Liu Haiming, Xie Zhiyuan, Liu Yannan. Strategic Thinking on the Transformation of Talents in Higher Vocational Education: Promoting the Integration of Industry and Education and the Development of Service Industry__ Also on the Talent Cultivation Strategy of "New Technology Application" in Higher Vocational Colleges [J]. Advanced Engineering Education Research, 2018, (02): 182-188.

[5] Zhou Ping. Research on the deep integration of school-enterprise cooperation in higher vocational colleges [J]. Education and Occupation, 2015, (13): 24-26. 